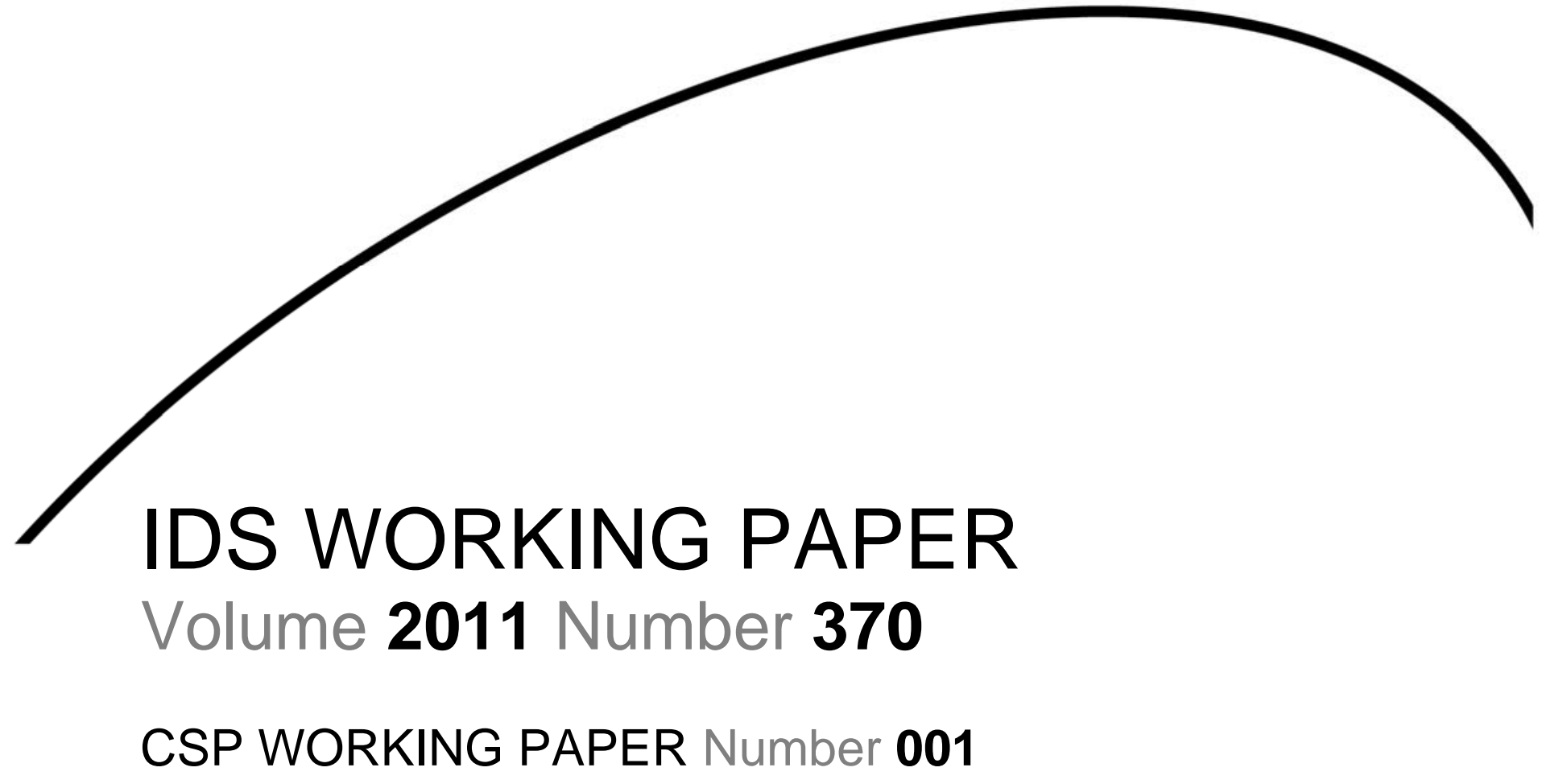

Social Protection and Socioeconomic Security in Nepal

Gabriele Koehler

August 2011

SP $\begin{aligned} & \text { Centre for } \\ & \text { Social Protection }\end{aligned}$ 
Social Protection and Socioeconomic Security in Nepal

Gabriele Koehler

IDS Working Paper 370

First published by the Institute of Development Studies in August 2011

(C) Institute of Development Studies 2011

ISSN: 1353-6141 ISBN: 978-1-78118-002-0

A catalogue record for this publication is available from the British Library.

All rights reserved. Reproduction, copy, transmission, or translation of any part of this publication

may be made only under the following conditions:

- with the prior permission of the publisher; or

- with a licence from the Copyright Licensing Agency Ltd., 90 Tottenham Court Road, London

W1P 9HE, UK,

or from another national licensing agency; or

• under the terms set out below.

This publication is copyright, but may be reproduced by any method without fee for teaching or nonprofit purposes, but not for resale. Formal permission is required for all such uses, but normally will be granted immediately. For copying in any other circumstances, or for reuse in other publications, or for translation or adaptation, prior written permission must be obtained from the publisher and a fee may be payable.

\section{Available from:}

Communications Unit, Institute of Development Studies, Brighton BN1 9RE, UK

Tel: +44 (0) 1273915637 Fax: +44 (0) 1273621202

E-mail: bookshop@ids.ac.uk

Web: www.ids.ac.uk/ids/bookshop

IDS is a charitable company limited by guarantee and registered in England (No. 877338) 


\title{
Social Protection and Socioeconomic Security in Nepal
}

\author{
Gabriele Koehler
}

\section{Summary}

Nepal, with a population of 27.6 million people, is a 'least developed country' in many ways. The country is characterised by significant socioeconomic insecurity, comprising structurallygenerated income poverty, a politically and socially fragile post-conflict situation, threats to the environment, and deeply entrenched forms of social exclusion. At the same time, it is a country characterised by interesting socio-political policy innovations, triggered by the end of a ten-year violent conflict. Building on a discussion of the country's challenges, the paper explores the policy responses in the domain of social protection devised by the interim government to address the various dimensions of insecurity, and to show their novelty as well as their limitations. The final section offers some ideas on policy areas which would be needed to improve socioeconomic security.

Keywords: socioeconomic security; social protection; social policy; poverty; social exclusion; Nepal

Gabriele Koehler is a Visiting Fellow at the Institute of Development Studies in the Vulnerability and Poverty Reduction team and affiliated with the Centre for Social Protection. She is doing research on the objectives and instruments of social protection policy in South Asia as expressions of a possible distinct welfare state approach in the region. Her interests and expertise include, inter alia, development policy and development agendas, notably the MDGs; concepts of human development and human security; economic and social policies around employment and decent work and social protection; and the history of development cooperation and UN history. Gabriele's background is in international development, having worked for many years as an economist with the UN. 


\section{Contents}

Summary, keywords and author note 3

Acknowledgements 4

Introduction $\quad 5$

1 Nepal, its four challenges in socioeconomic security and some interdependent root causes

2 Government responses to socioeconomic insecurity: recent social protection initiatives

$3 \quad$ The social protection initiatives: gauging initial outcomes 14

$4 \quad$ Elements of socioeconomic security at the country level: towards $\begin{array}{ll}\text { comprehensive and equitable social protection } & 16\end{array}$

$\begin{array}{lr}\text { Conclusion } & 18\end{array}$

$\begin{array}{ll}\text { References } & 19\end{array}$

Tables

Table 2.1 Social protection in Nepal: social transfer programmes $\quad 10$

Figures

Figure $1.1 \quad$ Human development index and its components by major caste and ethnicity, Nepal, 2006

Figure $1.2 \quad$ Human development index by major caste and ethnicity,

$\begin{array}{lll}\text { Figure 2.1 Nepal budget 2009/10 } & 13\end{array}$

$\begin{array}{ll}\text { Figure 2.2 } & \begin{array}{l}\text { Nepal budget 2009/10 - distribution of social services } \\ \text { (\% of total allocation) }\end{array}\end{array}$

\section{Acknowledgements}

This paper, in a way, is an outcome of my exposure to Nepal from 2005 to 2009. Numerous discussions with colleagues and friends, visits around Nepal, and literature, lectures and conferences on Nepal and South Asia shaped the approach taken in this paper. For specific comments on earlier versions of the paper, I would like to thank Aniruddha Bonnerjee, Marta Cali, Stephen Devereux, Shengjie Li, Gillian Mellsop, Rachel Sabates-Wheeler and Mariana Stirbu. Any remaining errors, omissions and misunderstandings are of course mine. 


\section{Introduction}

To those who stay, the soil.

To those who leave, the pathway.

Manjushree Thapa, The Tutor of History, New Delhi 2001

Nepal, with a population of 27.6 million people, is a 'least developed country'1 in many ways. The country is characterised by significant socioeconomic insecurity, comprising structurallygenerated income poverty, a politically and socially fragile post-conflict situation, threats to the environment, and deeply entrenched forms of social exclusion. At the same time, it is a country characterised by interesting socio-political policy innovations, triggered by the end of a ten-year violent conflict. Building on a discussion of the country's challenges, the paper explores the policy responses in the domain of social protection devised by the interim government to address the various dimensions of insecurity, and to show their novelty as well as their limitations. The final section offers some ideas on policy areas which would be needed to improve socioeconomic security.

\section{Nepal, its four challenges in socioeconomic security and some interdependent root causes}

Looking at Nepal's challenges, the most obvious one is perhaps its per capita income - the lowest in South Asia at US\$275 (current prices) or nominally US\$ 400 per capita (2005; World Bank, atlas method). Income inequality is among the highest in the South Asian region with a Gini coefficient of 0.41, increased from 0.31 between 1996 and 2003 (National Planning Commission of Nepal (NPC) 2007: 2).

Poverty ratios present a fuzzy picture. Measured as an absolute poverty line, it decreased from 42 to 31 per cent between 1996 and $2003,{ }^{2}$ and this is often interpreted as indicative of the country's economic progress. However, the more realistic poverty threshold (Bonnerjee and Koehler 2009) of $\$ 2$ per person per day shows that a staggering 77 per cent (World Bank) of Nepal's population continue to subsist in poverty. A large share of the population in Nepal face massive food insecurity. It is both structural - in the sense of deeply embedded, due to inequities in land and resources - and acute: as a result of the food price crisis of 2008, an estimated 6.5 to 10.5 million people or as many as 30 per cent of Nepal's population live in hunger, at least 2 million more than in 2005 (WFP 2009; UNICEF ROSA 2009; Koehler and Toole 2009). Child malnutrition affects 45 per cent of children under 5 (UNICEF 2010).

A second challenge comes from the continued political violence and an unsettled constitutional and political environment. The decade-long civil war which cost 11,000 lives

The term refers to a classification system of the UN Committee on Development Policy which identifies least developed countries (LDCs) based on per capita GDP, structural features and vulnerability, and Nepal is one of the current 49 LDCs (UNCTAD 2009). In a more substantive sense, too, as will be shown, it is indeed a country with very low development levels in any multidimensional sense of the concept.

Based on Nepal Living Standard Survey 2003/4, as per National Planning Commission of Nepal: 2. 
formally ended in 2006, so notionally Nepal is a post-conflict country, but violence remains prevalent in many parts of the country and so does impunity, both for conflict-related and for ongoing politically-motivated violence (Dixit 2007, 2009).

The degradation of the environment and recurrent natural disasters are a third key factor contributing to socioeconomic insecurity in a country situated in the increasingly vulnerable Himalayan range. Stress on the environment comes from global warming as well as from domestic factors, creating a situation with increasingly frequent natural disasters which displace large groups of the population as a result of floods, or undermine their livelihoods as a consequence of drought or landslides. The environment's deterioration is reflected in indicators such as the number of annual floods, droughts, landslides (UN DESA 2008).

In addition to pervasive structural income poverty, the post-conflict situation, and environmental threats, a fourth determinant of socioeconomic insecurity in Nepal comes from systematic social exclusion, based on multiple vectors of identity: gender, caste, ethnicity and language, location, age and ability, among others (Bennett 2006; Thorat 2008; Kabeer 2006; Koehler and Namala 2012 forthcoming). Gender systematically ascribes a structurally inferior role to women and girls in social, political and economic contexts. Caste and ethnicity-based exclusion creates a hierarchical structure with the so-called low caste groups seen to 'pollute' other castes if there is direct physical, or even social, contact (Thorat 2008).

As a combined result of economic poverty, conflict and violence, environmental degradation, and gender-, caste-, and ethnicity-based exclusion, Nepali society is highly stratified and riven. This finds expression in the human development index (HDI) which is the lowest in South Asia with the exception of Afghanistan - an indicator of Nepal's difficult socioeconomic situation. Although Nepal's HDI value and rank have been gradually improving over the past two decades (UNDP 2010), this is deceptive. Firstly, the improving trend line of the HDI is owed primarily to the increase in GDP per capita which is driven by factors such as increased informal sector labour - of the poor, and also of children and the elderly (Kyloh 2008: 141) and by remittance flows which may increase nominal incomes but come at the price of high socio-emotional costs. Secondly, the HDI captures neither income inequality, ${ }^{3}$ nor socioeconomic insecurity created by events and processes such as civil strife or social exclusion, nor environmental degradation. However, each of these are significant determinants of wellbeing in Nepal. Disaggregated by caste and ethnicity, it is as low as 0.383 for a highly disadvantaged group, the Madhesi Dalits, while it is significantly higher for the country's advantaged groups - reaching 0.616 for Newars or 0.625 for Madhesi Brahmin/Chhetri (see Figure 1.1 and 1.2; UNDP Nepal 2009: 44; data for 2006). 
Figure 1.1 Human development index and its components by major caste and ethnicity, Nepal, 2006

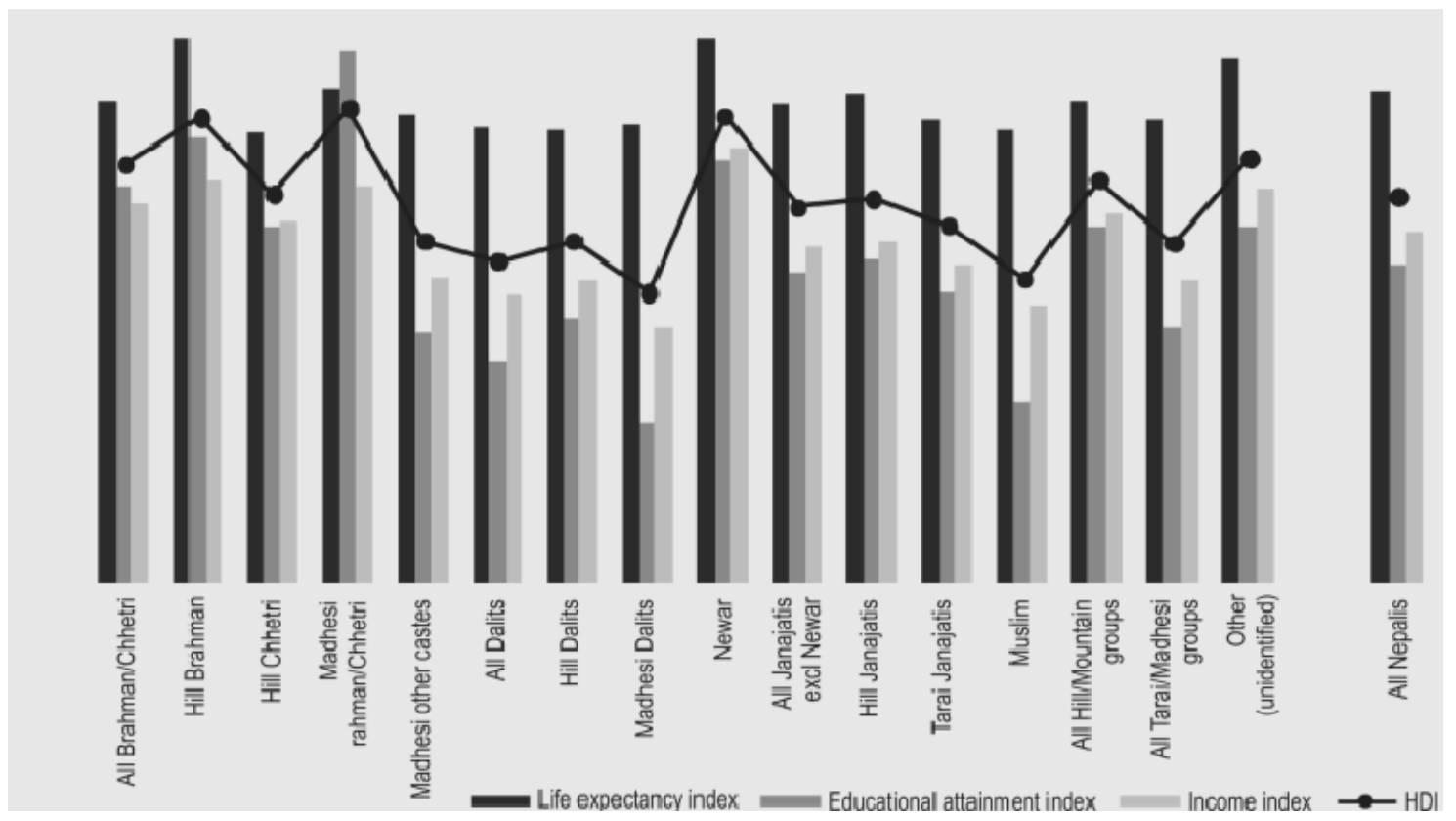

Source: UNDP Nepal (2009: 44)

Figure 1.2 Human development index by major caste and ethnicity, Nepal, 2006

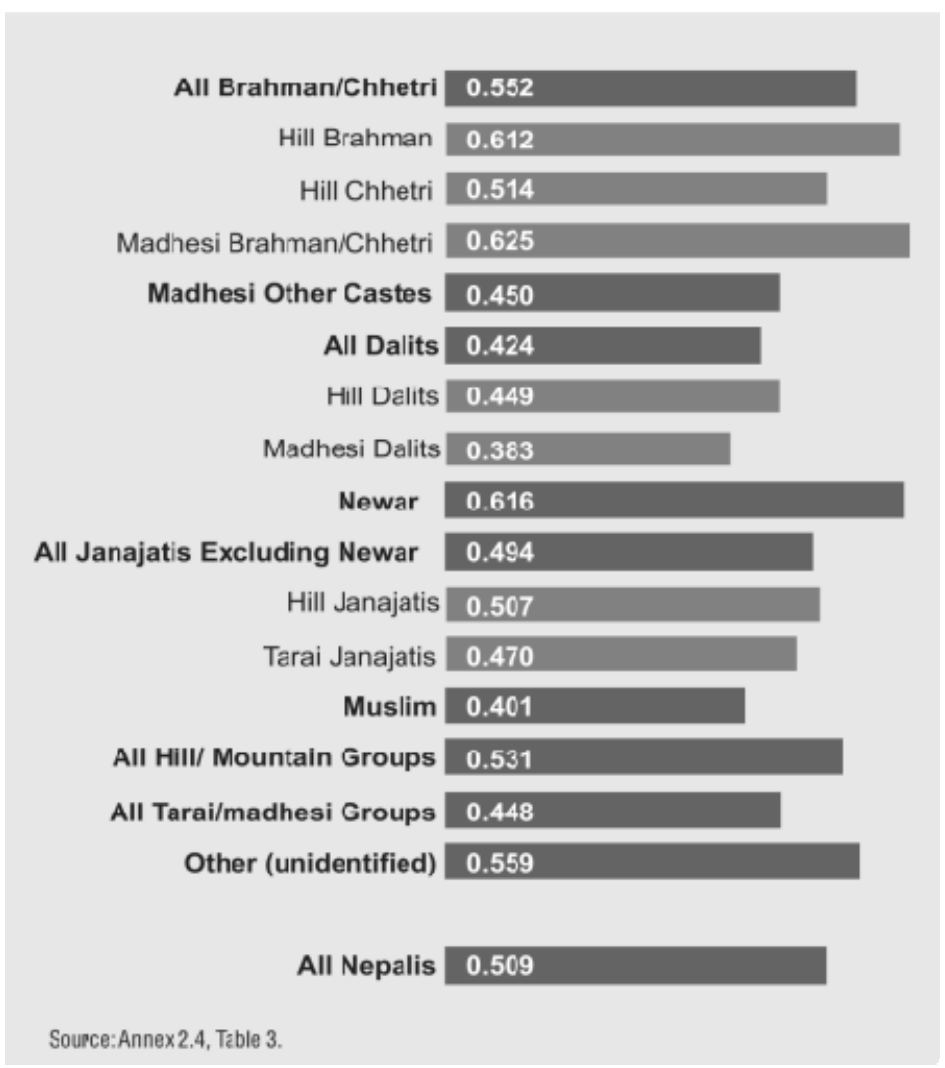

Source: UNDP Nepal (2009: 44) 
Other data too, confirm the social exclusion processes: while the national average literacy rate in 2001 stood at - an already extremely low - 54 per cent, it was only 33 per cent for Dalits and 40 to 50 per cent for indigenous groups (Janajati, Madhesi). Moreover, 'In all castes, the position of women is relatively lower than that of men in Nepal' (NPC 2007: 78). Average life expectancy of Dalit women, for example, is five years less than that of other women. Compounded exclusions - caste and gender, or ethnicity and gender - result in the lowest social indicator outcomes for women and girls in excluded communities. Age is another factor of discrimination with almost half of all children in Nepal suffering from malnutrition - a de facto denial of their right to food. An estimated 27 per cent of Nepali children in the 5 to 14 years age group are exploited as child labour (ILO, International Programme for the Elimination of Child Labour).

Causes for these difficult situations on the material level of socioeconomic security - or wellbeing - include the low levels of value added and productivity and skewed distribution of assets, and the associated low levels of remunerative employment. Formal sector employment hovers at 10 per cent. Unemployment and casualised, precarious informal sector employment are rampant (Vaidhya et al. 2010 citing Nepal labour force survey 2009). Agricultural productivity is constrained by inequality in land distribution notably in the terai (Southern flatlands), and moreover by geophysical factors in the mountainous areas of the country; manufacturing value added is inhibited by economic, social and political factors.

Assets and incomes are concentrated in the privileged groups. The so-called low caste groups are, in the aggregate, deprived of the means to have a sustainable income, savings and assets, and as a group they cluster in the lowest income quintile and under the poverty line. Between 1996 and 2004, poverty decreased by 46 per cent for the advantaged castes (Brahmin and Chhetri), but only by 21 per cent for Dalits (NPC 2007: 77), so that the income gap between them actually increased.

ILO data suggest that there has been little socioeconomic progress over the past decade: the number of working poor at the $\$ 1$ per day poverty line is estimated to have increased from 2.5 million adults in 1991 to 3.2 million in 2005; the number of working poor at \$2 per day increased from 5.8 million to 8 million. This would mean that 34 per cent of the working population were earning less than $\$ 1$ and more than four fifths - 84 per cent - were earning less than $\$ 2$. This is not enough to lift themselves and their families out of poverty (Kyloh 2008: 136).

Socioeconomic insecurity is rife. Informal, family- or community-based systems of social protection are disintegrating with poverty, urbanisation and changes in traditional family structures. As one result, migration has become a key 'coping' strategy and defining feature of Nepal's socioeconomic structure. Up to 25 per cent of the unskilled population of Nepal migrate recurrently, either within Nepal, across the immediate border to India, or internationally. ${ }^{4}$ While the freedom of movement is a right that deserves support, the conditions of migration, and the fact that much of Nepal's migration is distress driven, suggest that migration is one of the most visible actions taken to address socioeconomic insecurity (WFP 2008). In the districts/countries of destination, unskilled migrants frequently work in the informal economy at the lowest levels of wages, and in in-country and local cross-border migration, usually deprived of basic labour rights. In international migration, work contracts are generally in place, but political rights are usually not in force. ${ }^{5}$ On the emotional level, the isolation of low-skilled migrants who generally migrate alone and for long

As much as 27 per cent of GDP is generated by remittances (WFP 2008).

Anecdotal reports including in documentary film footage record systematic seizure of the migrants' ID so that they are unable to leave the country without the employer's consent. See for instance Tseten (2009). 
stretches of time is a considerable cost to wellbeing. ${ }^{6}$ And formal social security entitlements rarely accrue in these casual, informal sector jobs. One question, and the query driving this paper, is therefore: what is the government doing to address socioeconomic insecurity?

\section{Government responses to socioeconomic insecurity: recent social protection initiatives}

The government of Nepal, elected as an interim government and operating under an interim constitution since 2007, acknowledged these socioeconomic insecurities when it took office. Thus, the National Planning Commission of Nepal's (NPC) interim development plan (2007/8 to 2009/10) singles out poverty and social exclusion, as the root causes of the civil war (NPC 2007: 111) and points to the country's structural economic problems such as inequitable access to productive resources and means, distributional conflict and shortfalls in good governance' (NPC 2007: 1) as well as caste discrimination and violation of human rights (ibid.). The declared goal of this new government was to make society 'equitable by reducing the existing regional, class, caste/ethnicity and other disparities and discriminations' (NPC 2007: 77).

The Plan's thematic areas, policies and instruments derive from this analysis and are meant to redress the social and economic injustices. The Plan sets the vision of a 'prosperous, modern and just Nepal' and posits economic and social transformation as the main objective (NPC 2007: 26). It focuses on post-conflict relief, reconstruction and reintegration, employment oriented pro-poor growth, good governance and effective service delivery, increased investment in infrastructure, as well as inclusive development (NPC 2007: 26); it promotes 'geographical, economic, social [and] gender solidarity' (NPC 2007: 28). Key features include a growth strategy with emphasis on the market and FDI and a minor role ascribed to public works schemes (NPC 2007: 85).

The Three-Year Development Plan (2010/11 to 2013), which followed on the initial postconflict plan, is conceptualised as an employment oriented approach, framed in the inclusive growth paradigm. Launched in 2011, it is introducing innovations such as a quantified employment target, with a notion of productive employment that is to bring wages above the poverty line. It is based on a projection of expected new labour market entrants, plus persons employed in unproductive jobs and, with an assumption of constant employment elasticity of GDP growth, stipulates a GDP growth rate of 6.35 per cent, and 4.4 per cent per capita for the plan period. It also looks into sectors where employment elasticity is larger than 1 and comes to some sector polices which would favour employment-intensive growth (Campbell 2010).

Beyond the verbal commitments expressed in the current development plan, the actual expenditure patterns of the post-conflict governments have been in tune with the ambitions laid out in the interim development plan. The fiscal budgets of 2007/8 and 2008/9 have been expansionary. Increased budget outlays have been partly covered by rising tax revenue. The

To communicate with their loved ones, migrants give a - free - missed call from their mobiles at evening time, a symbol of their permanent physical insecurity - they are still alive and well - and their loneliness (Tseten 2009). 
latter was due to better tax compliance and resumed macroeconomic and external trade growth since 2008.

Social protection transfers have become a highly visible component in social policy since 2008 (see table 2.1), building on a complex web of social protection instruments, some of which have been in place in Nepal since pre-conflict periods.

Table 2.1 Social protection in Nepal: social transfer programmes

\begin{tabular}{|c|c|c|c|c|c|}
\hline Type & Primary objective & Elements & $\begin{array}{l}\text { Geographical } \\
\text { arealentitlement }\end{array}$ & Administration & Funding source \\
\hline $\begin{array}{l}\text { Formal } \\
\text { sector social } \\
\text { security and } \\
\text { health } \\
\text { insurance }\end{array}$ & $\begin{array}{l}\text { Insurance against } \\
\text { unemployment, sickness, } \\
\text { accident and for old age }\end{array}$ & $\begin{array}{l}\text { Covers only small } \\
\text { segment of } \\
\text { population in the } \\
\text { formal sector - } \\
\text { government civil } \\
\text { servants, army, } \\
\text { police, teachers }\end{array}$ & $\begin{array}{l}\text { Formal sector, } \\
\text { nationwide }\end{array}$ & $\begin{array}{l}\text { Ministry of } \\
\text { Labour }\end{array}$ & $\begin{array}{l}\text { Government, } \\
\text { employers, } \\
\text { employees }\end{array}$ \\
\hline Food aid & $\begin{array}{l}\text { Address extreme hunger } \\
\text { and malnutrition }\end{array}$ & $\begin{array}{l}\text { Public food } \\
\text { distribution system } \\
\text { and food for work } \\
\text { schemes }\end{array}$ & $\begin{array}{l}\text { Dependent on } \\
\text { area affected }\end{array}$ & & $\begin{array}{l}\text { Government and } \\
\text { aid agencies }\end{array}$ \\
\hline $\begin{array}{l}\text { School meal } \\
\text { programmes }\end{array}$ & $\begin{array}{l}\text { Address malnutrition and } \\
\text { serve as incentive for } \\
\text { school attendance }\end{array}$ & $\begin{array}{l}\text { Public and UN } \\
\text { agencies }\end{array}$ & $\begin{array}{l}\text { All government } \\
\text { primary schools }\end{array}$ & $\begin{array}{l}\text { Ministry of } \\
\text { Education }\end{array}$ & \\
\hline $\begin{array}{l}\text { Employment } \\
\text { schemes }\end{array}$ & $\begin{array}{l}\text { Rural employment and } \\
\text { rural infrastructure; Karnali } \\
\text { Employment Programme } \\
(\text { KEP): } \\
\text { 'One family one job' }\end{array}$ & $\begin{array}{l}\text { Public or } \\
\text { development } \\
\text { agency-based } \\
\text { public works - } \\
\text { cash for work }\end{array}$ & Karnali Zone & $\begin{array}{l}\text { Ministry of } \\
\text { Labour/Ministry } \\
\text { of Local } \\
\text { Development }\end{array}$ & $\begin{array}{l}\text { Government and } \\
\text { aid agencies }\end{array}$ \\
\hline $\begin{array}{l}\text { District block } \\
\text { grants and } \\
\text { top up grants }\end{array}$ & $\begin{array}{l}\text { Funds to finance local } \\
\text { governance and } \\
\text { community development }\end{array}$ & & $\begin{array}{l}\text { All } 75 \text { districts of } \\
\text { the country } \\
\text { planned }\end{array}$ & $\begin{array}{l}\text { Ministry of Local } \\
\text { Development }\end{array}$ & \\
\hline $\begin{array}{l}\text { Disability } \\
\text { allowance }\end{array}$ & $\begin{array}{l}\text { For persons living with } \\
\text { disability or sight- } \\
\text { impairedness, as per MLD } \\
\text { criteria }\end{array}$ & $\begin{array}{l}500-1000 \text { rupees } \\
\text { per month, } \\
\text { depending on } \\
\text { severity }\end{array}$ & All disabled & $\begin{array}{l}\text { Ministry of Local } \\
\text { Development }\end{array}$ & Government \\
\hline $\begin{array}{l}\text { Social } \\
\text { pensions }\end{array}$ & Security for the elderly & $\begin{array}{l}\text { Entitlement for all } \\
\text { citizens over age } \\
\text { of } 70, \text { and over } 60 \\
\text { in Karnali Zone, or } \\
\text { if identified as } \\
\text { Dalit community, } \\
\text { currently rupees } \\
500 \text { per month }\end{array}$ & $\begin{array}{l}\text { Legally, all } \\
\text { eligible as per } \\
\text { the categorical } \\
\text { targeting }\end{array}$ & $\begin{array}{l}\text { Government, } \\
\text { distributed by } \\
\text { local } \\
\text { administration of } \\
\text { Ministry of Local } \\
\text { Development }\end{array}$ & Government \\
\hline $\begin{array}{l}\text { Widows' } \\
\text { grant }\end{array}$ & Social assistance & $\begin{array}{l}\text { Widows over } 60 \text {, } \\
\text { means-tested }\end{array}$ & & & Government \\
\hline $\begin{array}{l}\text { Health } \\
\text { access } \\
\text { subsidies }\end{array}$ & $\begin{array}{l}\text { Reduce maternal and } \\
\text { infant mortality through } \\
\text { birth assistance }\end{array}$ & $\begin{array}{l}\text { Birth grants - } \\
\text { medical and } \\
\text { transport costs }\end{array}$ & & $\begin{array}{l}\text { Government, } \\
\text { distributed by } \\
\text { local health } \\
\text { workers/midwives }\end{array}$ & Aid agencies \\
\hline
\end{tabular}




\begin{tabular}{|c|c|c|c|c|}
\hline $\begin{array}{l}\text { Education } \\
\text { grants }\end{array}$ & Social inclusion & $\begin{array}{l}\text { For socially } \\
\text { excluded groups - } \\
\text { girl children, Dalit } \\
\text { children }\end{array}$ & $\begin{array}{l}\text { Government, } \\
\text { distributed by } \\
\text { local } \\
\text { administration of } \\
\text { Ministry of } \\
\text { Education }\end{array}$ & Government \\
\hline $\begin{array}{l}\text { Technical } \\
\text { education } \\
\text { scholarship } \\
\text { for girl } \\
\text { children }\end{array}$ & Gender equality & $\begin{array}{l}\text { For girl students in } \\
\text { low-income } \\
\text { families in } \\
\text { disadvantaged } \\
\text { regions and } \\
\text { communities }\end{array}$ & & \\
\hline $\begin{array}{l}\text { Categorical } \\
\text { grant for } \\
\text { 'threatened } \\
\text { ethnicities' }\end{array}$ & $\begin{array}{l}\text { Social inclusion and } \\
\text { diversity }\end{array}$ & $\begin{array}{l}\text { For all members of } \\
\text { ethnic or language } \\
\text { communities with } \\
\text { small and } \\
\text { declining numbers } \\
\text { of people } \\
\text { Benefit of rupees } \\
500 \text { per month, } \\
\text { and } 1000 \text { rupees } \\
\text { for most at risk } \\
\text { community to } \\
\text { attend technical } \\
\text { college }\end{array}$ & $\begin{array}{l}\text { Government, } \\
\text { distributed by } \\
\text { local } \\
\text { administration of } \\
\text { Ministry of } \\
\text { Education }\end{array}$ & Government \\
\hline Child benefit & Address child malnutrition & $\begin{array}{l}\text { For Dalit children } \\
\text { from birth til } 5 \\
\text { years, two children } \\
\text { under-5 children } \\
\text { per family, in low } \\
\text { income } \\
\text { households; for all } \\
\text { families Karnali } \\
\text { Zone, benefit of } \\
\text { rupees } 200 \text { per } \\
\text { month per child }\end{array}$ & $\begin{array}{l}\text { Government, } \\
\text { distributed by } \\
\text { local } \\
\text { administration of } \\
\text { Ministry of Local } \\
\text { Development }\end{array}$ & $\begin{array}{l}\text { Government } \\
\text { Ministry of Local } \\
\text { Development } \\
\text { and Ministry of } \\
\text { Child and } \\
\text { Women Welfare }\end{array}$ \\
\hline $\begin{array}{l}\text { Geographical } \\
\text { grant }\end{array}$ & Address remoteness & $\begin{array}{l}\text { For disadvantaged } \\
\text { groups such as } \\
\text { Dalits, single } \\
\text { women and } \\
\text { people living in the } \\
\text { Karnali Zone }\end{array}$ & & \\
\hline $\begin{array}{l}\text { Marriage } \\
\text { allowance }\end{array}$ & Social inclusion & $\begin{array}{l}\text { Grant for wedding } \\
\text { expenses for } \\
\text { widows from } \\
\text { socially excluded } \\
\text { groups and inter- } \\
\text { caste marriages. } \\
\text { Benefit of rupees } \\
50000-100000\end{array}$ & $\begin{array}{l}\text { Government, } \\
\text { distributed by } \\
\text { local } \\
\text { administration of } \\
\text { Ministry of Local } \\
\text { Development }\end{array}$ & \\
\hline $\begin{array}{l}\text { Monthly } \\
\text { allowances } \\
\text { for ex- } \\
\text { combatants }\end{array}$ & Political stability & $\begin{array}{l}\text { Introduced as part } \\
\text { of the Peace } \\
\text { Agreement in } \\
2006 / 7\end{array}$ & Government & $\begin{array}{l}\text { Ministry of } \\
\text { Interior and } \\
\text { Nepal Army }\end{array}$ \\
\hline $\begin{array}{l}\text { Subsistence } \\
\text { allowance for } \\
\text { families } \\
\text { affected by } \\
\text { the civil war }\end{array}$ & $\begin{array}{l}\text { Political stability and social } \\
\text { justice }\end{array}$ & $\begin{array}{l}\text { Allowances to } \\
\text { families of those } \\
\text { who perished or } \\
\text { became disabled } \\
\text { during the civil war }\end{array}$ & & \\
\hline
\end{tabular}

Source: compiled from Koehler, Cali and Stirbu (2009b: 22 and 60-7); Government of Nepal, Ministry of Local Development (2009); Dhakal (2010). 
Building on, but expanding from, the interim development plan, the Nepal fiscal budget 2008/9 introduced social policy interventions to create employment and some additional social protection transfers. The existing public works programmes were complemented by a specific programme in the most remote and disadvantaged area in Nepal, the Karnali Zone, called the Karnali Employment Programme (KEP) offering 'One family one job'. The objective is to offer social protection through short-term employment and to create or preserve social and economic assets.

The scheme was introduced in fiscal year 2006/7, and adopted as a policy in 2010, modelled on the Mahatma Gandhi National Rural Employment Guarantee Act of India. It is designed to provide 100 days of paid employment at 180 to 350 rupees per day on government infrastructure programmes for persons willing to do unskilled manual work, at a wage fixed at the district level. Similar to the Indian approach, it guarantees a social transfer if employment on a public works scheme is not made available. The KEP works with user groups who indentify the project areas and sites. There is a commitment to include all castes, which appears to be met, while women and youth employment impact are lagging (Koehler, Cali and Stirbu 2009b: 63; Vaidya et al. 2010).

The Karnali Zone, with the five North-western districts of Dolpa, Humla, Jumla, Kalikot and Mugu, is the poorest region of Nepal: income poverty is estimated at 50 per cent, due to the region's lack of productive cultivable land, poor climate, remoteness and mountainous terrain. The annual government budget allocations over the past four fiscal years have increased from Rs. 180 million to Rs. 225 million. Approximately 60,000 households are eligible for participation, which would suggest a need for 6 million workdays each year, if every eligible household applied. The fiscal budget allocations allow for roughly 878,000 to 1 million work days at a daily wage of 200 rupees, averaging 15 days per person. In the first four years of the programme, based on a sample household survey, households were found to have worked 30 days or less (Vaidya et al. 2010).

The district block grants - introduced in 20 districts by end 2007 and to be scaled up to all 75 districts - are provided to fund infrastructure building, and distributed on a formula based on size of the population, size of the district, HDI, cost of living index, and revenue generation (Koehler, Cali and Stirbu 2009a: 62). The KEP and the block grants could become elements in social protection that could contribute to structural change, provided that the choice of infrastructure schemes and specific locations are decided democratically, do not re-enforce but rather tackle social exclusion and locational inequities, and raise the local wage levels.

The universal old age pension - introduced in 1995 - was enhanced, by lowering the entitlement age from 75 to 70 years, and doubling the benefit from 250 to 500 rupees per month. Very significantly, free healthcare services at sub health posts, health posts and district hospitals have been introduced - a significant step, since the costs of health care are a prime driver of socioeconomic insecurity.

The 2009/10 fiscal budget introduced a child benefit as a new type of social transfer (Government of Nepal, Ministry of Finance 2010). The child benefit was initially conceptualised as a universal child grant, similar to that available in some high income countries. However, in light of budget constraints as well as with a view to the novelty of the scheme, the child grant was instead adopted in the form of a categorically targeted grant to all families in the Karnali Zone, as mentioned above the poorest districts in the country, and to all 'poor' (or low-income) Dalit households throughout the country. Poor households are defined as being landless or having minute landholdings. The entitlement is 200 rupees per child for up to two children under 5 years per family, and if there are more than two children, 
it is the girl children who are to be registered. ${ }^{7}$ The purpose of the grant is primarily to assist families in offering better nutrition and accessing health services for the very young children (see Government of Nepal, Ministry of Local Development $2009\left(2066^{8}\right)$ ).

A glance at the 2009/10 fiscal budget (Government of Nepal, Ministry of Finance 2010 and figures 2.1 and 2.2) shows that almost half of the fiscal budget is allocated to the social sector; and that education services, which includes the stipends, and the transfers of the Ministry of Local Development are the two largest allocation heads, with respectively 42 per cent and 23 per cent of the total social budgets. However, an itemised breakdown of each of the social protection transfers is not available.

Figure 2.1 Nepal budget 2009/10

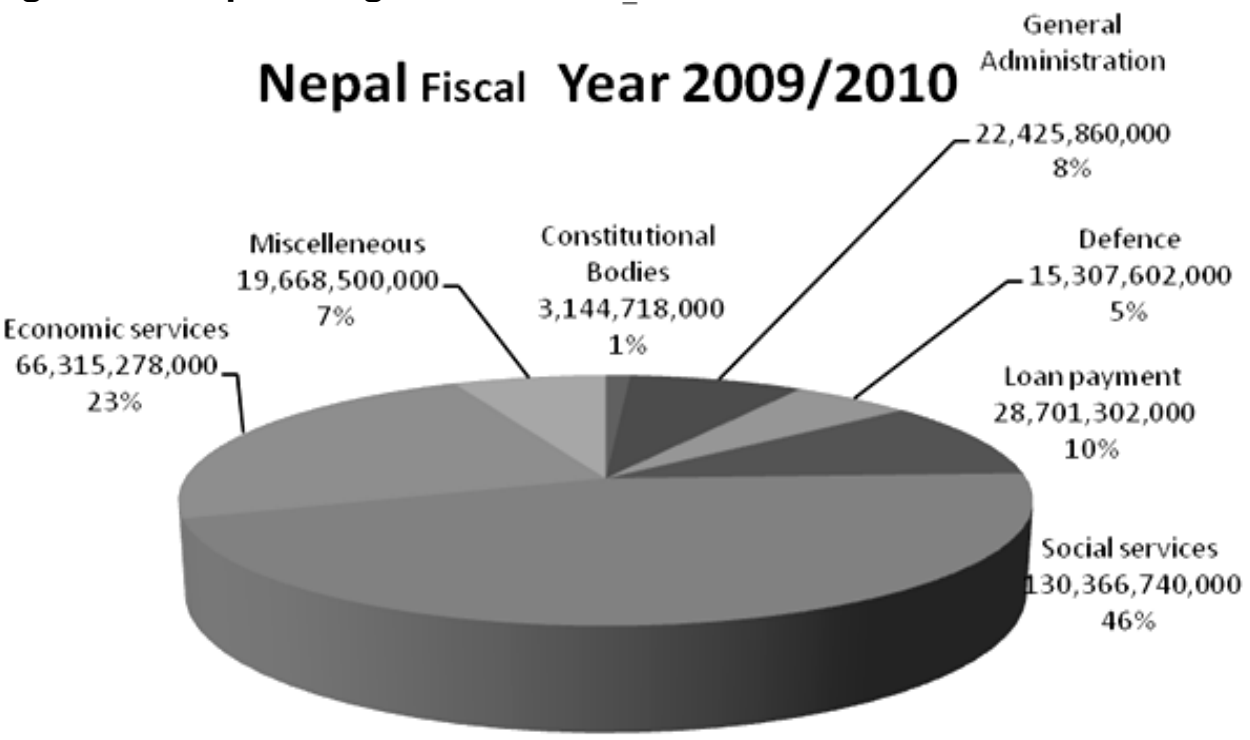

Total Budget : Rs.285,930,000,000.00 (285.93 billion)

Source: Dhakal (2010: 3).

The limitation to two children per family is a measure introduced to encourage child spacing and not encourage population growth. District officials were however in discussion with the Ministry of Local Development because of the implementation difficulties of this modality.

8 The official Nepali Calendar follows Bikram Samwat (BS) - the BS year is 56.7 years ahead of the (western) Gregorian Calendar 


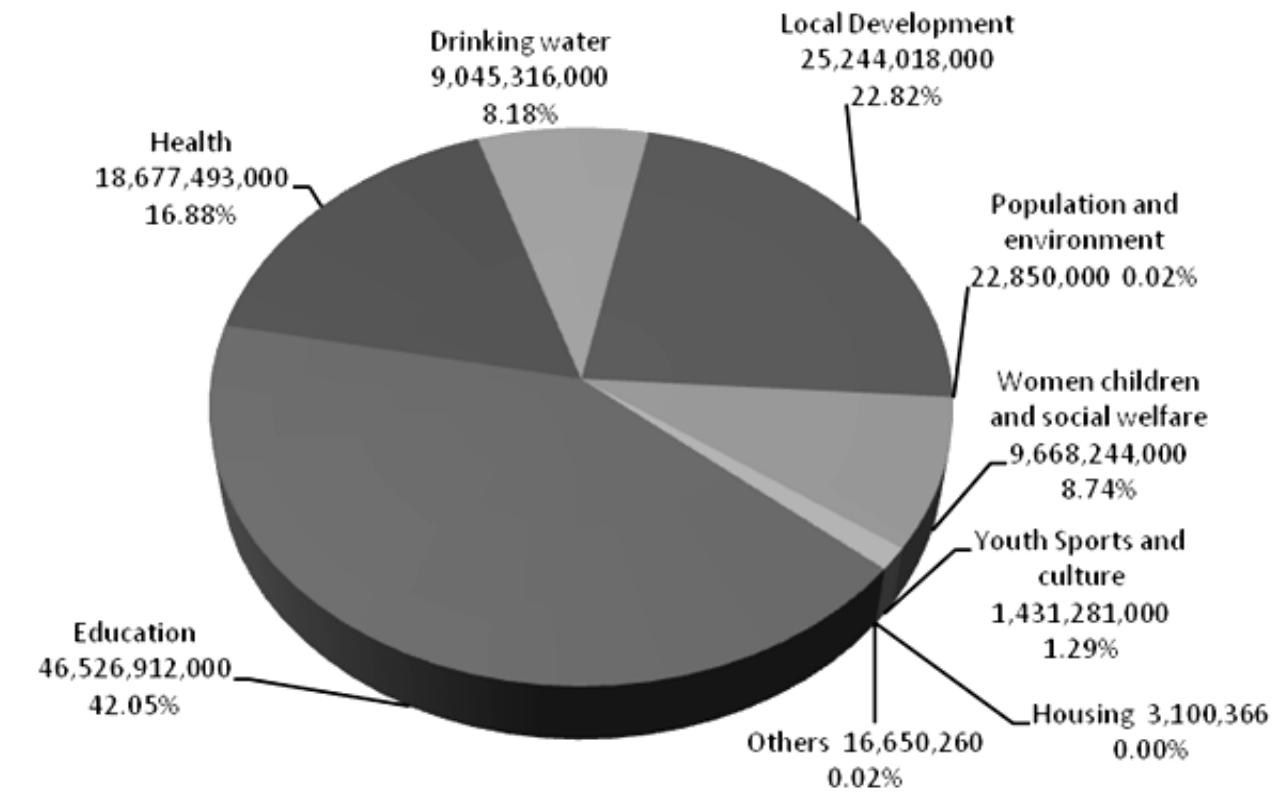

Source: Dhakal (2010: 3).

These are some of the innovative social transfers available, at the programme level, in Nepal at this time.

\section{The social protection initiatives: gauging initial outcomes}

The question arises whether these social protection schemes are appropriate and adequate to address Nepal's four socioeconomic challenges.

A first observation would be that the social protection instruments in Nepal are conceptually a response to insecurity in that they are rights based. Some are universal, by category, such as the old age pension or the education stipends, or the child grant, or geographical, as the KEP, while others are targeted, with clearly defined recipients, so that they come close to categorical transfers. The majority of social protection schemes are in the fiscal budget and tax-financed, with only a few pilots financed by donors. They therefore can be interpreted as elements in a nascent social contract.

From the angle of government provisioning for social protection - and for social services more widely - the programmes are of interest because of the space they are accorded in the fiscal budget. The social expenditures for health, education, water and sanitation together have constituted approximately 30 per cent of the fiscal budget for the past several budget years (UNICEF ROSA fiscal budget database). Within the social budget, health and education are on average allocated 15 and 46 per cent respectively, which, in terms of relative shares, compares favourably to other developing countries. Thus, Nepal has exceeded the Copenhagen Social Summit goals of 1995 of earmarking at least 20 per cent 
of the fiscal budget for social expenditures (see also UNICEF Nepal 2007). So, to some extent, one could argue that socioeconomic security is being addressed systemically.

There are, however, considerable challenges and issues at the design, delivery and monitoring stages. The actual coverage achieved by the schemes offers a mixed picture. An index, developed by the Asian Development Bank (ADB 2007) to assess coverage and quality of social protection, ranks Nepal's social protection system at 0.17 on a scale of 0 to 1. This is very low but exceeds the ratio expected of a country at this economic level (ADB 2008). ${ }^{9}$ Despite the universal approach of some of the schemes, coverage rates for the key social protection groups - the unemployed, the underemployed, the elderly, the sick, the poor, people living with disability and children with special needs - vary widely, from an estimated 30 per cent of the elderly to under 10 per cent of the disabled or those entitled to health insurance. The same estimates suggest that only 2.3 million people receive any form of social protection transfers (ADB 2007: 216). This would be less than 10 per cent of the population.

A second systematic deficiency is that the per capita expenditures for each of the social sector budget heads and social transfers are very low in per cent of GDP or in value terms, averaging \$8 for education and \$3 for health per person per year (2000-2007 average, UNICEF ROSA fiscal budget data base). This is because the share of the fiscal budget in the GDP is at only 12 per cent. In the medium term, increased tax revenues as a combined result of more tax compliance and a marginal increase in GDP growth and more trade tax could result in higher tax to GDP and expenditure to GDP ratios. With associated political will and public pressure, this growing government income could be appropriated for additional socioeconomic security related expenditures.

A third, and related, shortcoming is that the outcomes of public social expenditures, expressed in nutrition, education, health or poverty outcomes, are not commensurate with the financial outlay made within the fiscal budget. As mentioned above, economic and social outcomes are on extremely low levels and highly skewed by caste, ethnicity and gender. So, contrary to the pronounced commitments, socioeconomic security is far from materialising.

Reasons for this cleavage between policy commitments and actual implementation are manifold. They include the fragmented nature of the many social protection transfers and the low levels of the actual monetary benefits. On the supply side, many additional factors come together, undermining any genuine improvement in socioeconomic security. They include the overall low quality of health and education services, their difficult access, the pervasive and painful social exclusion experienced in daily life in service delivery, and the low level of public awareness of schemes for which they are eligible and to which they have a right. Accountability to citizens is not institutionalised. So, even where there are clear entitlements, the transfers are not sufficient in monetary terms, not adequate in terms of quality, and not universal in political terms. This leads to significant delivery failures.

Another shortcoming is of an especially complex nature: some forms of social transfers, introduced with the express aim of overcoming social exclusion, such as the school stipends for Dalit children, may - inadvertently - reinforce exclusion. They may, for example, cement social divisions as they reinforce existing group identities and become instrumentalised by identity politics. The social transfers have, so far, not been able to contribute to the deep structural transformation required to address socioeconomic security. 
Structurally, and this is the most defining shortcoming, although there are many types of transfers, none are directed at building productive assets at the household level. Ultimately, however, productive assets in the household are the only substantive way to overcome poverty, and social protection transfers aimed at asset building could at least at the margin help address structural poverty.

Finally, there is the challenge of the political situation. Governance remains weak; local authorities are not in control in several parts of the country; mismanagement as well as outright corruption continues. The peace process stalls, with constitution writing and military integration not progressing as laid out in the peace agreement, so that political and individual insecurity characterise the situation in several regions of Nepal.

\section{Elements of socioeconomic security at the country level: towards comprehensive and equitable social protection}

This paper has used the concept of socioeconomic insecurity, stemming from four factors, in its discussion of social protection programmes in Nepal. In an attempt to 'imagine' a better approach to insecurities, one can introduce the notion of socioeconomic security, a concept that can be associated with a striving for 'wellbeing and flourishing for all' (Saith 2008: 19; Gough and Wood 2004). The notion addresses the multiplicity of human rights and development requirements, and spans social and economic development. Inherent to this approach is that socioeconomic security needs be universalised, both from a methodological and from a normative perspective. Rights are not divisible and cannot be targeted to a subgroup of a population, which implies that equity is integral to this notion.

Secondly, there is a realist or pragmatist case for adopting a rights-based approach: if income levels are low as they are in Nepal, and income inequality is large and increasing, there is a case for universalised approaches, as they are easier to administer and can be the most effective way to spread impact. Policies for economic and social security in poor countries need to address almost the entire population, and an effective way to do this is to address the entire population. As one respondent in a Nepal survey put it 'How can you single out the poorest in a sea of poor?' (quoted in Koehler, Cali and Stirbu 2009a).

Thirdly, there is an economic argument for a comprehensive social protection programme. The fiscal stimulus packages introduced in the recent economic and financial crisis augmented the incomes of the lowest income quintiles, and contributed at least marginally to improving their socioeconomic security. They also helped reignite economic growth by stimulating demand. The propensity to spend can be expected to be highest among the lowest income groups, thus getting the strongest multiplier effect from public transfers designed as socioeconomic security measures. Economic security and economic recovery can cohere.

Socioeconomic security thus offers an overarching normative as well as economics-based and pragmatic framework for designing and assessing social protection measures. Using a socioeconomic security framework, the following section offers a tentative proposal on addressing socioeconomic insecurity in Nepal.

If one 'bundles' socioeconomic security - or wellbeing - together with different sets of policies, one can suggest 'alternative packages of universalism', in the sense of different 
combinations of areas of socioeconomic security and pertaining enabling factors and policies. ${ }^{10}$ In the case of Nepal, they need to address income insecurity, environmental insecurity, social exclusion, and the aftermath of the violent conflict.

A list of 'basic constituents' of socioeconomic security ${ }^{11}$ might encompass:

a) Security of income, including decent work and social protection transfers and would need to include access to assets such as land, or capital, or resources;

b) Social inclusion and participation and voice;

c) Political cohesion or nation building and political security - freedom from violence and coercion;

d) Measures to reinforce environmental sustainability.

These four areas are of course far from sufficient. For a transformation from the inequitable and exclusionary outcomes experienced in Nepal - as in many other countries - it is necessary that institutions and service delivery points are reformed and transformed. Policies need to be comprehensively integrated across the political, the social, the ecological, and the cultural or identity domains. This includes, but reaches far beyond, the linchpin of all socioeconomic security domains - that of the economy. Equally importantly, an impartial, professional parliament, a genuinely 'civil' and egalitarian civil society and a free investigative press are needed to control and check the development state and make sure the population has voice and is empowered.

For a country such as Nepal, what does this mean? The brief description of the aspirations of the national development plan and social protection instruments suggests that the state in Nepal sees itself with responsibilities ranging from public food provisioning in times of distress through basic social services provision, to environmental management and social inclusion. The policy measures introduced in recent fiscal budgets place much emphasis on social protection in the wide sense.

The role, and the limitations, of social protection becomes clear: various forms of social protection transfers can address immediate income and food insecurity, be a ladder towards decent work and productive employment, and be tools of affirmative action to overcome social exclusion, and help with political healing. ${ }^{12}$

However, beyond the immediate support, the disconnect between aspiration and delivery is a fundamental one because it perpetuates socioeconomic insecurity. To improve on the social protection schemes put in place, several political elements would need to be institutionalised:

- Combining technocratic, knowledge-based ${ }^{13}$ policy decisions with participative, rightsbased normative approaches.

10 See for instance Saith (2008) for a discussion of elements constituting socioeconomic security.

11 Creating lists such as this can be situated in a tradition of social imaginaries - using imagination to expand the situations considered possible. See Schrecker 2010, referring to Donna Haraway. The approach is also rooted in the Universal Declaration of Human Rights which, in some ways, was a design for a better, socially more just world. all households with children across the country, regardless of their political stance and economic position. See Koehler Cali, Stirbu (2009a).

13 Currently, the development discourse is oriented towards evidence based policy decisions. However, there may be insufficient, evaluated evidence for a given sectoral policy or policy instrument. Knowledge on policy 'toolkits' and their history is needed, and if empirical experience with a given approach in specific environment is missing, this should not necessarily become an obstacle to introducing a policy based on political, normative or analytical assessments or principles. 
- $\quad$ Ensuring and monitoring the political will and capacity to deliver.

- $\quad$ Ensuring the predictability of resources required to deliver public goods and services, in reliably high and consistent quality, and inclusively, including transparency and equity in the social protection transfers.

- $\quad$ Garnering public support for raising the tax to GDP ratio to create fiscal space for socioeconomic security, and, in tandem, redress income inequality.

- Enabling fundamental reform of institutions of service delivery.

- Introducing some reconfiguration of the social protection system, to consolidate it, make it more transparent, accountable, increase efficiency, and raise the fiscal resources available, so that actual benefits can be augmented, and contribute to income redistribution, for example via instruments of progressive taxation.

- $\quad$ Ensuring the real empowerment of citizens to define and claim their entitlements and rights. The role of a right to public information is crucial here. ${ }^{14}$

A renewed focus on constitutional rights and entitlements, and a supportive national framework for social policy and social protection is also required in order to ensure greater coherence and coordination of sectoral and cross-sectoral policy areas towards establishing and maintain a socioeconomic security environment in Nepal.

\section{Conclusion}

Socioeconomic security in Nepal moreover requires social policy including social protection measures at the regional level. These would need to harmonise labour legislation and social protection across South Asia so as to cut through the race to the bottom which propels and perpetuates socioeconomic insecurity. ${ }^{15}$ Elements could include portable rights to free primary health care services, access to drinking water, and an entitlement for all children, of citizens or of migrants, to school meals, compulsory education. It would need to work on a minimum wage threshold across borders. It could also include basic social protection measures across South Asia, by regionalising legislation, coverage and delivery. A beginning would be to adopt, harmonise, and provide the resource for implementation and monitoring, the ILO core labour conventions and the convention on social security, as well as the ILO conventions on homework, on migration and on discrimination. The CEDAW and the Convention of the Rights of the Child have been ratified by all South Asian countries and their real implementation could be a beginning towards address some of the problems. The Convention on the Eradication of all Forms of Racial Discrimination, recently ratified by Nepal is a third international framework of key relevance to inform inclusive policy making.

A combined national-level and regional approach could begin a process of transforming social protection towards assuring universal, inclusive socioeconomic security. 


\section{References}

Asian Development Bank (ADB) (2007) Scaling Up of the Social Protection Index for Committed Poverty Reduction, Manila, www.adb.org (accessed 29 July 2011)

Bennett, L. (2006) Unequal Citizens. Gender, Caste and Ethnic Exclusion in Nepal. Executive Summary, Kathmandu: DFID/World Bank

Bonnerjee, A. and Koehler, G. (2009) 'The 3 Fs Crisis in South Asia', mimeo, published as 'Südasien: Wie die Dreifache Krise Frauen und Kinder Trifft', in UNICEF (2010), UNICEF-Report 2010. Kinder - die Vergessenen der Finanzkrise, Frankfurt: Fischer: $37-68$

Campbell, D. (2010) 'The Non-mystery of Employment-led Growth', Inter-Agency Technical Meeting, Building Employment and Decent Work into Sustainable Recovery and Development - The UN Contribution, Turin, 29 November to 1 December 2010

Dhakal, T. (2010) Nepal Budget 2009/2010. Social Protection Perspective, UNICEF Nepal: Kathmandu

Dixit, K. (2009) Never Again. Testimonies from the Nepal Conflict, Kathmandu: Nepa-laya

_ (2007) A People War. Images of the Nepal conflict 1996-2006, Kathmandu: Nepa-laya

Gough, I. and Wood, G. (2004) 'Introduction' in I. Gough, and G. Wood, Insecurity in Welfare Regimes in Asia, Africa and Latin America. Social Policy in Development Contexts, Cambridge: Cambridge University Press: 1-11

Government of Nepal, Ministry of Finance (2010) Public Statement on Income and Expenditure of Fiscal Year 2010/11, Kathmandu

Government of Nepal, Ministry of Local Development 2066 (2009) Child Protection Grant Operational Procedure 2066, Kathmandu

ILO, Child Labour Statistics, www.ilo.org/ipec (accessed 29 July 2011)

Kabeer, N. (2006) 'Social Exclusion and the MDGs: The Challenge of "Durable Inequalities" in the Asian Context', paper presented at the Asia 2015 conference, Promoting Growth, Ending Poverty, IDS and ODI

Koehler, G. and Namala, A. (2012) Social Exclusion in South Asia, forthcoming

Koehler, G. and Toole, D. (2009) 'The Impact of the Crisis on Children: A Policy View from South Asia', Global Social Policy 9: 16-20

Koehler, G.; Calì, M. and Stirbu, M. (2009a) 'Rethinking Poverty and Social Exclusion Responses in Post-Conflict Nepal: Child-Sensitive Social Protection', Children, Youth and Environments 19.2

Koehler, G.; Stirbu, M. and Cali, M. (2009b) 'Social Protection in South Asia. Overview', UNICEF, Regional Office South Asia: Kathmandu 
Kyloh, R. (2008) From Conflict to Cooperation. Labour Market Reforms that can Work in Nepal, Geneva: ILO, and New Delhi: Academic Foundation

National Planning Commission (NPC) (2007) Government of Nepal, Three Year Interim Plan -2007/08-2009/10, Singhdurbar, Kathmandu, December

National Planning Commission Secretariat (NPC) (2004) Central Bureau of Statistics, Nepal Living Standard Survey 2003/4, Thapathali, Kathmandu, December

Saith, A. (2008) 'Towards Universalizing Socio-economic Security: Strategic Elements of a Policy Framework', Indian Journal of Human Development 2.1, Delhi: Institute for Human Development: 9-38

— (2004) Social Protection, Decent Work and Development, Discussion Paper 152, Geneva: ILO

Schrecker, T. (2010) 'Against the Marketplace', Global Social Policy 10.2: 154-8

Thapa, M. (2001) The Tutor of History, New Delhi: Penguin

Thorat, S. (2008) 'Social Exclusion in the Indian Context: Theoretical Basis of Inclusive Policies', Indian Journal of Human Development 2.1, Delhi: Institute for Human Development: 165-81

Tseten, K. (2009) In Search of the Ryal, documentary film, Kathmandu

UN DESA (2008) World Economic and Social Survey 2008. Overcoming Economic Insecurity, www.un.org./esa/policy/wess (accessed 29 July 2011)

UNCTAD (2009) Least Developed Countries Report 2009, Geneva: United Nations

UNDP (2010) Human Development Report, New York: Oxford University Press

UNDP Nepal (2009) Human Development Report 2009. State Transformation and Human Development, Kathmandu

UNICEF (2010), State of the World's Children (SOWC), New York

UNICEF Nepal (2007) An Analytical Study of Basic Social Services in Nepal, 2006, National Planning Commission/UNICEF, Institute for Sustainable Development

UNICEF Regional Office South Asia (ROSA) Fiscal Budget Database

UNICEF Regional Office South Asia (ROSA) (2009) A Matter of Magnitude. The Impact of the Economic Crisis on Women and Children in South Asia, Kathmandu: UNICEF

Vaidya, K.; Regmi, P.P. and Ghimire, B. (2010) Appraisal of the Karnali Employment Programme as a Regional Social Protection Scheme, Kathmandu: ILO

World Bank South Asia, www.worldbank.org/southasia (accessed 29 July 2011)

World Food Programme (WFP) Nepal (2008) Passage to India. Migration as a Coping Strategy in Times of Crisis in Nepal. Implications for WFP Responses, Kathmandu: United Nations 